\title{
White Heart in Pons-A Rare Imaging Sign in Bilateral Pontine Infarction
}

\author{
Syed T. Fazal ${ }^{1}$ Ashima Mahajan ${ }^{1}$ Sanjay Mehta ${ }^{1}$ \\ 1Department of Radiodiagnosis, Artemis Hospital, Gurgaon, \\ Haryana, India
}

J Neuroanaesthesiol Crit Care 2022;9:68-70.

An 89-year-old hypertensive male presented to a local hospital with a history of sudden onset dizziness and two episodes of vomiting after having dinner. On neurological examination, he was drowsy with mild weakness in all the four limbs. He progressively developed tetraplegia within 2 hours of admission and was immediately shifted to our tertiary care center in the emergency department, where he suddenly developed loss of consciousness. He became nonresponsive with a Glasgow coma scale (GCS) of E2V1M2. His plantar reflex was bilaterally extensor. He urgently required ventilator support. Routine biochemical tests including serum electrolytes, electrocardiogram, and transthoracic echocardiogram were within normal limits. Magnetic resonance imaging (MRI) brain was performed, which showed acute infarct in bilateral pons with characteristic white heart appearance on diffusion-weighted image (DWI), T2-weighted and fluid-attenuated inversion recovery (FLAIR) axial images ( - Fig. 1). Contrast-enhanced MRI (CEMRI) was also performed, which showed filling defect in midbasilar artery, suggestive of thrombus, resulting in near complete occlusion with posterior eccentric filling. There was normal

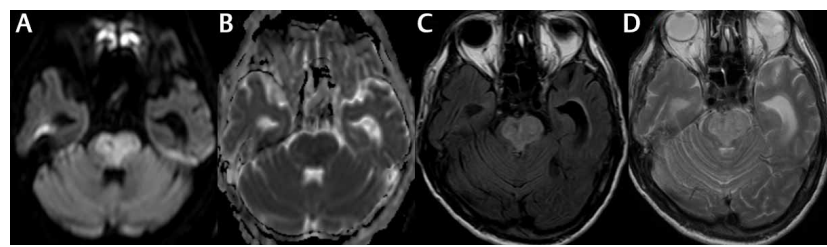

Fig. 1 Magnetic resonance imaging (MRI) brain. (A, B) Diffusionweighted image (DWI) and corresponding apparent diffusion coefficient (ADC) map show acute pontine infarct with a characteristic "heart appearance." (C, D) Axial T2-weighted and fluid-attenuated inversion recovery (FLAIR) images show the same "heart-shaped" hyperintensity in pons.
Address for correspondence Ashima Mahajan, MD, DNB, Department of Radiodiagnosis, Artemis Hospital, Sector 51, Gurgaon, Haryana 122001, India (e-mail: ashima.mahajan88@yahoo.in).

opacification of distal basilar artery partially, because of retrograde flow from right posterior communicating (PCom) artery (-Fig. 2). Mechanical thrombectomy was not offered in view of large volume infarct in pons. The patient died of cardiopulmonary complications on the second day of his admission.

The heart-shaped sign in medulla on MRI due to bilateral medial medullary infarction is uncommon, however many cases are featured in literature. ${ }^{1,2}$ The pattern of vascularization of pons is somewhat similar to that of medulla, and thus it may encounter similar heart-shaped appearance in pons also. However, white heart appearance on MRI in bilateral pontine infarction is extremely rare. To date, there are only four cases of white heart appearance in the pons on MRI axial images reported in the literature (- Table 1) $)^{3-6}$ In addition to that, Kumral et $\mathrm{al}^{7}$ mentioned 14 cases of bilateral anteromedial pontine infarcts, out of which 7 cases had the heart-shaped appearance, although they never mentioned this rare appearance. In most of the previously reported cases of heart-shaped appearance of pons, there was normal basilar artery on angiography ${ }^{3,5,6}$ Venkatesan et al ${ }^{4}$ also reported a case of heart-shaped infarct in pons due to underlying severe atherosclerotic changes in vertebral and basilar artery. This suggests the likely possibility of small artery disease or basilar artery atheroma as an etiology for white heart-shaped appearance of pontine infarct. The present case is another example of bilateral pontine infarction due to thrombus in basilar artery, resulting in near complete occlusion; however, the presence of associated underlying atherosclerotic disease cannot be ruled out, as the contrast angiography or digital subtraction angiography (DSA) was not done in our case. The blood supply to the pons from basilar artery is via threes branches and is depicted schematically in $\boldsymbol{- F i g}$. 3 . The paramedian branches (7-10) supply the anteromedial pons; published online

November 14, 2021
DoI https://doi.org/

$10.1055 / \mathrm{s}-0041-1739344$ ISSN 2348-0548
(C) 2021. Indian Society of Neuroanaesthesiology and Critical Care. All rights reserved.

This is an open access article published by Thieme under the terms of the Creative Commons Attribution-NonDerivative-NonCommercial-License, permitting copying and reproduction so long as the original work is given appropriate credit. Contents may not be used for commercial purposes, or adapted, remixed, transformed or built upon. (https://creativecommons.org/licenses/by-nc-nd/4.0/).

Thieme Medical and Scientific Publishers Pvt. Ltd. A-12, 2nd Floor, Sector 2, Noida-201301 UP, India 


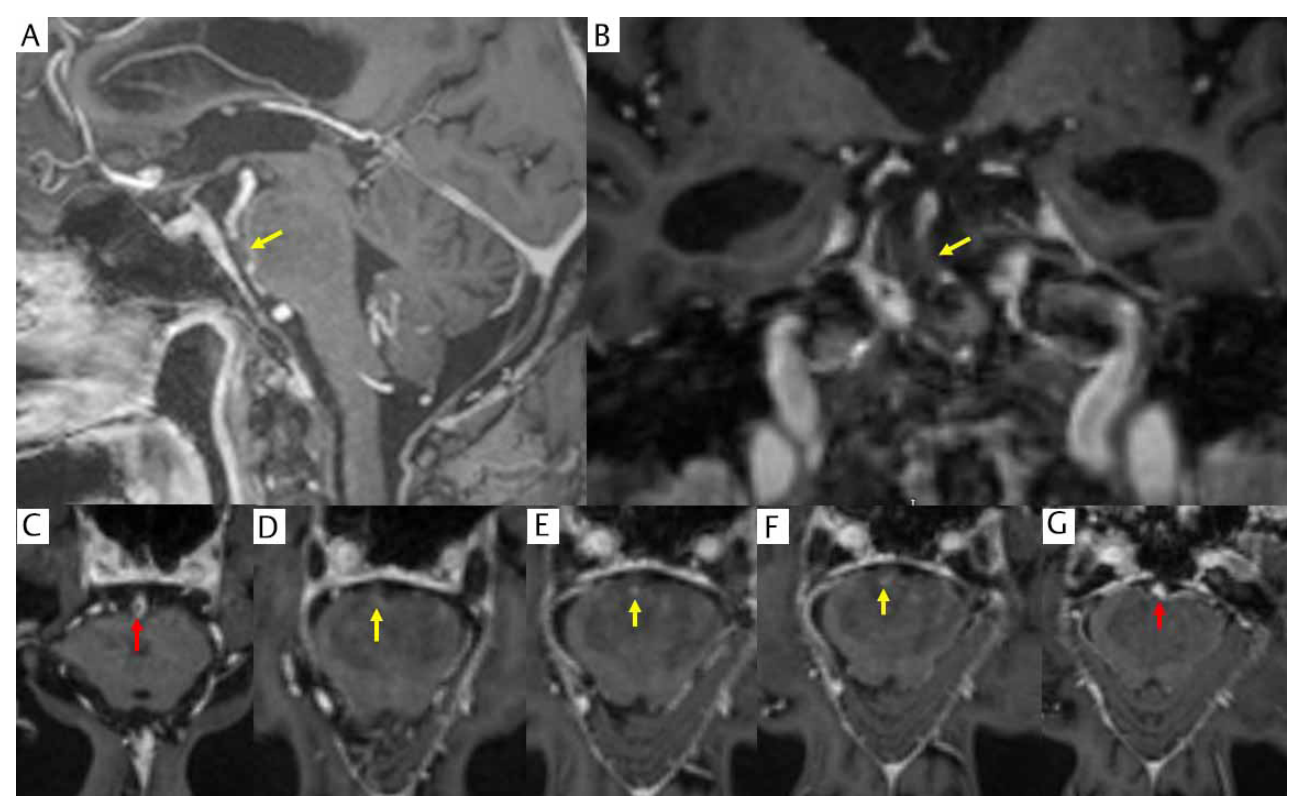

Fig. 2 Contrast-enhanced magnetic resonance imaging (CEMRI) of brain (A, B) Sagittal and coronal T1-weighted, maximum intensity projection (MIP) images show basilar artery near complete occlusion (arrow). (C-G) Axial postcontrast images showing thrombus in basilar artery with thin eccentric filling of contrast (yellow arrows) and opacified basilar artery proximal and distal to it (red arrow).

Table 1 Reported case of heart-shaped appearance of infarct in pons

\begin{tabular}{|l|l|l|l|l|l|}
\hline $\begin{array}{l}\text { Author's name } \\
\text { (year) }\end{array}$ & Age/sex & $\begin{array}{l}\text { Clinical } \\
\text { presentation }\end{array}$ & $\begin{array}{l}\text { Location of heart- } \\
\text { shaped infarct }\end{array}$ & $\begin{array}{l}\text { Angiography } \\
\text { findings/CEMRI } \\
\text { findings }\end{array}$ & $\begin{array}{l}\text { Final outcome of the } \\
\text { patient }\end{array}$ \\
\hline Ishizawa et al ${ }^{5}$ & $87 Y / M$ & Tetraparesis & Pons & $\begin{array}{l}\text { Normal basilar artery } \\
\text { on MRA }\end{array}$ & Tetraplegic \\
\hline $\begin{array}{l}\text { Venkatesan } \\
\text { et al }{ }^{4}\end{array}$ & $53 \mathrm{Y} / \mathrm{M}$ & $\begin{array}{l}\text { Vertigo, } \\
\text { slurred speech, } \\
\text { tetraplegia }\end{array}$ & Pons & $\begin{array}{l}\text { Diffuse atherosclerotic } \\
\text { disease of the vertebral } \\
\text { and basilar arteries on } \\
\text { MRA }\end{array}$ & Tetraplegic \\
\hline Sen et al ${ }^{3}$ & $60 \mathrm{Y} / \mathrm{M}$ & $\begin{array}{l}\text { Dizziness, } \\
\text { Unsteady gait, } \\
\text { tetraparesis }\end{array}$ & Pons & $\begin{array}{l}\text { Normal basilar artery } \\
\text { on MRA }\end{array}$ & $\begin{array}{l}\text { Died of cardiorespiratory } \\
\text { complications }\end{array}$ \\
\hline Zhou et al ${ }^{6}$ & $67 / \mathrm{F}$ & $\begin{array}{l}\text { Vertigo, nausea, } \\
\text { vomiting, dys- } \\
\text { arthria, bilateral } \\
\text { facial weakness, } \\
\text { tetraplegia }\end{array}$ & $\begin{array}{l}\text { Pontomedullary } \\
\text { junction }\end{array}$ & $\begin{array}{l}\text { Normal basilar and ver- } \\
\text { tebral artery on DSA }\end{array}$ & $\begin{array}{l}\text { Tetraplegic (upper and lower } \\
\text { limb with grade } 2 \text { power), } \\
\text { dysarthria, bilateral facial } \\
\text { weakness and nasal feeding }\end{array}$ \\
\hline Present case & $89 \mathrm{Y} / \mathrm{M}$ & $\begin{array}{l}\text { Vomiting, altered } \\
\text { sensorium and } \\
\text { tetraplegia }\end{array}$ & Pons & $\begin{array}{l}\text { Near complete occlu- } \\
\text { sion of basilar artery on } \\
\text { CEMRI }\end{array}$ & $\begin{array}{l}\text { Died of cardiopulmonary } \\
\text { complications }\end{array}$ \\
\hline
\end{tabular}

Abbreviations: CEMRI, contrast-enhanced magnetic resonance imaging; DSA, digital subtraction angiography; MRA, magnetic resonance angiography.

short circumferential branches (5-7) supply the anterolateral pons and the middle and superior cerebellar peduncles; and paired long circumferential branches (superior cerebellar and anterior inferior cerebellar arteries) supply the lateral territory. ${ }^{3,4}$ There should be bilateral involvement of the anteromedial and the anterolateral arterial territories, with sparing of the lateral territories to have the white heart appearance of infarct in the pons.

This characteristic appearance of white heart may also mimic pontine glioma and osmotic myelinolysis. Diffuse pontine glioma occurs in children, usually expands, and distorts the pons with no or minimal diffusion restriction on MRI. Osmotic myelinolysis presents with a history of rapid correction of hyponatremia, and it usually spares the periphery of the pons. ${ }^{3}$ Overall outcome of bilateral pontine infarction is poor with severe morbidity and mortality (-Table 1). Therefore, early clinical diagnosis and detection of subtle findings on MRI is critical in these cases, so that appropriate timely intervention can be offered to such patients. 


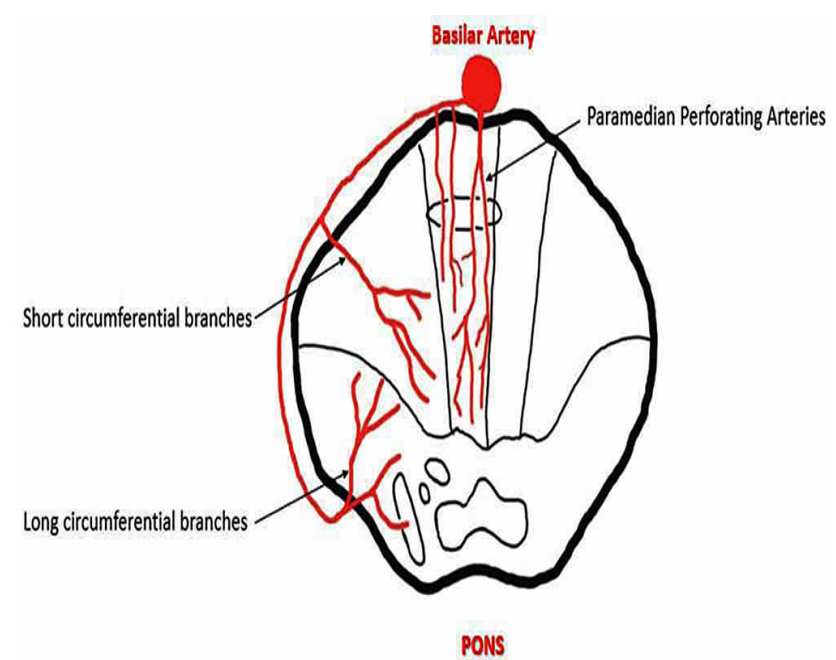

Fig. 3 Schematic diagram showing three arterial territories of pons.

\section{Conflict of Interest}

None declared.

\section{References}

1 Torabi AM. Bilateral medial medullary stroke: a challenge in early diagnosis. Case Rep Neurol Med 2013;2013:274373

2 Krishnan M, Rajan P, Kesavadas C, Iyer RS. The "heart appearance' sign in MRI in bilateral medial medullary infarction. Postgrad Med J 2011;87(1024):156-157

3 Sen D, Arora V, Adlakha S, Gulati YS, Doppaladudi A, Tiwary $\mathrm{S}$. The "heart appearance" sign in bilateral pontine infarction. J Stroke Cerebrovasc Dis 2015;24(1):e21-e24

4 Venkatesan P, Balakrishnan R, Ramadoss K, Iyer RS. Heart appearance sign in pontine stroke: a result of bilateral infarction due to small vessel disease. Neurol India 2014;62(1):115-116

5 Ishizawa K, Ninomiya M, Nakazato Y, Yamamoto T, Araki N. "Heart appearance" infarction of the pons: a case report. Case Rep Radiol 2012;2012:690903

6 Zhou ZH, Wu YF, Wu WF, et al. Giant "heart appearance-like sign" on MRI in bilateral ponto-medullary junction infraction: case report. BMC Neurol 2020;20(1):107

7 Kumral E, Bayülkem G, Evyapan D. Clinical spectrum of pontine infarction. Clinical-MRI correlations. J Neurol 2002;249(12):1659-1670 